\title{
STRATEGY ANALYSIS OF SMALL-SCALE BUSINESS DEVELOPMENT OF LEATHER PRODUCTS IN SIDOARJO REGENCY OF EAST JAVA, INDONESIA
}

\author{
Triswanto Edi, Ratnawati Tri, Susanti Nanis \\ 17 Agustus 1945 University, Surabaya, Indonesia \\ E-mail: editriswanto62@gmail.com
}

\begin{abstract}
Micro, Small and Medium Enterprises of East Java has contributed $54.34 \%$ to the total value of Gross Regional Domestic Product of the region. Various problems experienced by the leather processing industry located in Sidoarjo and Surabaya. These problems include management which includes poor accounting system and procedures, transaction recording is still done manually and do not have profit balance report. The purpose of this research is to know the strengths, weaknesses, opportunities, and threats faced by the leather craftsmen in Surabaya and Sidoarjo in the short and long term and to know how the participation of local government and related agencies in developing leather processing industry in these two locations.
\end{abstract}

\section{KEY WORDS}

Strategy, SWOT, small business, leather, revolution 4.0, innovation.

The history of skin-processing crafters in Tanggulangin - Sidoarjo started in 1939 and these skills were handed down from generation to generation as some of the crafters in Tanggulangin Sidoarjo started making bags, suitcases and other processed leather products. In 1976, the Intako Cooperative (industrial bag and suitcase) was established with only 27 members. Currently, Intako Cooperative continues to grow to have 350 more members of crafters. The occurrence of Lapindo mud disaster in 2006 had decreased the visitors drastically resulted in bankruptcy of $70 \%$ craftsman. Some of them only work if there is an order. MSMEs accounted for $54.39 \%$ of all industries in East Java. In addition to prospering business actors, MSMEs can also help the government to cope with unemployment. 2013 BPS data shows that the number of MSMEs in East Java is 6,825,931. Every year the contribution of MSMEs is always improving. In 2012 the role of MSMEs to East Java GRDP is $54.39 \%$ of total East Java GRDP of 1,0011.72 Trillion, one of the existing MSMEs in East Java is the leather craft industry in Sidoarjo.

The results of preliminary observations indicate that there are various problems experienced by the skin processing industry located in Sidoarjo. These problems include management such as poor bookkeeping procedures; recording transactions are still done using systematic manual using a computer, and does not have a balance sheet of profit and loss. The Value Chain raw material supply becomes one of the problems experienced by industrial owners because the supply chain is also influenced by large leather processing companies in Sidoarjo which have exported their products abroad. One of the causes of the lack of optimal assistance done by the local government is that the difficulty in uniting and cooperating among crafters, the lack of promotion by LG and INTAKO, in general, the crafters do not have their own brand. Thus, most of their products will be sold again by the entrepreneurs using another brand. The phenomenon of small entrepreneurs, especially the processed leather crafters becomes the focus of this research. The purpose of this research is to know the result of internal factor analysis and external factor with SWOT and to give strategic plan to improve the competitiveness of leather crafters.

\section{MATERIALS AND METHODS OF RESEARCH}

Research to be reviewed by researchers is a matter of a social and dynamic nature. The further research method used is qualitative research method by using phenomenology 
analysis. SWOT analysis is used to determine the internal and external conditions of leather handicraft to be developed as appropriate strategy to improve the quality, productivity and improve the competitiveness and selling value of handicraft processed leather industry in the form of bag, luggage, and others.

The research was conducted in leather industry area located in Tanggulangin Sidoarjo. The data were collected by interview questionnaire and recording process was also done to the interview. The data retrieval and field observation were conducted from January 2017 to March 2018.

The informant of this research consists of 6 people who are the owner of leather processing business in Sidoarjo. Secondary research data is also obtained from the Department of Trade, Department of MSME of Sidoarjo Regency.

\section{RESULTS OF STUDY}

Internal factors (Strengths):

- Product quality. The product quality is excellent because it comes from $100 \%$ genuine leather for the genuine leather type.

- Design. The products of the processed leather crafters of Intako members vary greatly. Product design updates are also continuing to follow the market demand and popular trends.

- Skill. Most of the crafters who joined the cooperative Intako have good skills and the skills have been passed down from their parents. The additional workforces who work in their business place also have proven their skills and ability to produce excellent quality goods.

- Internet. Most of the crafters have been using the internet to search for up to date new designs and always try to keep up with the current trends.

- Time of product work. Crafters have a commitment to be able to complete the order in accordance with the agreed time specified with consumers. Up until now, all orders are completed in a timely manner.

- Brand. Some have their own brand name making it easier for consumers to remember the brand.

- Consumer Warranty. The crafters provide the warranty to the consumer. The warranty is either free repair or replacement with a new product. This warranty will provide satisfaction and increase consumer confidence in the product.

Internal factors (Weaknesses):

- Capital from Bank Loans. The derived capital comes from the Bank's credit and part of the cooperative's savings. Loan obtained from the Bank will have an impact on the interest payable by crafters. The existence of this interest will have an impact on the increasing production costs.

- The Profit and Loss Balance Sheet have not been performed. Bookkeeping and recording of profit and loss on a regular basis should be done.

- Raw material. High-quality leather raw materials are difficult to obtain. Currently, the supply of raw materials also depends on the private company. Some auxiliary materials should be imported due to the limited material.

- Cleanliness and Safety Factors. All raw materials need to be cleaned in accordance with applicable procedures. The company should pay attention to the health of the crafters especially to the Work Health and Safety and Occupational Diseases

- No business entity. Most crafters do not have registered business entity. The business is only run by individual.

- Poor purchasing system of raw material. Value chain supply of raw materials is still poor. Sometimes, raw materials have been sold out while the product of sales results has not been sold. This makes the production does not work well and hampers the productivity. 
Table 1 - Internal Matrix of Small Processed Leather Products in Sidoarjo Regency

\begin{tabular}{|c|c|c|c|c|}
\hline & Internal factors & Weight & Rating & Weighted Score \\
\hline \multicolumn{5}{|c|}{ Power: } \\
\hline$\bullet$ & Quality Product & 0.3 & 4 & 1,2 \\
\hline - & The designs vary & 0.05 & 3 & 0.15 \\
\hline - & Have skills & 0.15 & 4 & 0.6 \\
\hline - & Utilizing the Internet & 0.05 & 3 & 0.15 \\
\hline - & Work on time & 0.05 & 3 & 0.15 \\
\hline - & Own brand & 0.2 & 4 & 0.8 \\
\hline$\bullet$ & Providing warranty to the production results & 0.2 & 4 & 0.8 \\
\hline Total & & - & - & 3.85 \\
\hline \multicolumn{5}{|c|}{ Weakness: } \\
\hline • & Capital from Bank loan & 0.3 & 4 & 1,2 \\
\hline - & Incorrect financial records & 0.2 & 3 & 0.6 \\
\hline - & Poor estimation of raw materials & 0.15 & 3 & 0.45 \\
\hline - & Health protection is not a priority & 0.05 & 3 & 0.15 \\
\hline - & Do not have a business entity & 0.2 & 4 & 0.8 \\
\hline$\bullet$ & Do not have standard purchase system & 0.1 & 3 & 0.3 \\
\hline Total & & - & - & 3.5 \\
\hline
\end{tabular}

External Factors (Opportunities):

- Buyers know the quality of the product results. The quality of the processed leather products from Tanggulangin, Sidoarjo is well-known in the market. Hence, the quality of the products is not questionable. The public trust can increase the selling value of the product.

- Competitive price. The price offered by the crafters is relatively cheaper when compared with similar products from abroad. A cheaper price with a similar quality product will make its position as the main choice in the market.

- Leather processed enthusiasts are still high. The interest in leather products is still high, especially middle to upper class. For them, it is necessary to have high-quality products in order to show their social strata.

- No competitors. There is no competitor which a serious barrier to the sustainability of this product can be.

External Factors (Threats):

- Imitation of raw materials and accessories depending on import. Imitations of raw materials, auxiliary materials and many accessories that must be imported have increased the production costs. In addition, the dependence of this material can obstruct the production process; the import process also takes longer which obstruct the production process.

- Not Optimal Role by the Government. The role of government in developing MSMEs should be improved. According to Law No. 20 of 2008 on MSME stating that the government and local government have to facilitate the development of MSMEs in the field of production and processing, marketing, human resources, design, and technology. One of the business developments facilitated by the government is to provide easiness in the procurement of facility and infrastructure, production and processing, raw materials, auxiliary materials, and packaging for MSMEs products. The results of this study indicate that the role of government is still not optimal in developing MSMEs. The role of government needs to be revived in terms of assistance. Thus, MSMEs, especially small-scale entrepreneurs of processed leather (crafters) can grow and survive well. In addition, they will be encouraged more to improve its competitiveness.

- The implementation of the sale and purchase transaction is not in accordance with the agreement. In the execution of sale and purchase transactions, there are still cases in which the buyer does not pay or pick up goods at the completion time of ordered of processed leather products. This has obstructed the flow funds which in turn affect or disturb the production process. 
Table 2 - External Matrix of Small Processed Leather Products in Sidoarjo Regency

\begin{tabular}{|c|c|c|c|}
\hline External Factors & Weight & Rating & Weight score \\
\hline \multicolumn{4}{|l|}{ Opportunities: } \\
\hline - $\quad$ Buyers know the quality of the products & 0.3 & 4 & 1.2 \\
\hline - Has a competitive price with other products & 0.3 & 4 & 1.2 \\
\hline - $\quad$ High interest in leather products & 0.2 & 3 & 0.6 \\
\hline - No competitor has tried to bring down the manufacturer yet & 0.2 & 3 & 0.6 \\
\hline Total & - & - & 3.6 \\
\hline \multicolumn{4}{|l|}{ Threat: } \\
\hline $\begin{array}{ll}\text { - Imitation raw materials and accessories still depend on } \\
\text { imports }\end{array}$ & 0.3 & 4 & 1,2 \\
\hline - $\quad$ The role of the government is limited to providinginformation & 0.5 & 4 & 2.0 \\
\hline $\begin{array}{l}\text { - Implementation of the sale and purchase is not in } \\
\text { accordance with the agreement }\end{array}$ & 0.2 & 4 & 0.8 \\
\hline Total & - & - & 4.0 \\
\hline
\end{tabular}

The results of IFAS and EFAS calculations show that the weighted value is in the ST quadrant position ST. The difference in the weighted value of the internal factor is 0.35 while for the external factor is -0.4 . This shows that the craft of leather products has internal strength but has external threat.

Table 3 - The Value of Weighted Difference of Internal and External Factors

\begin{tabular}{|l|l|}
\hline Weighted Value of Strength & 3.85 \\
\hline Weighted Value of Weaknesses & 3.5 \\
\hline Difference & 0.35 \\
\hline Weighted Value of Opportunity & 3.6 \\
\hline Weighted Value of Threat & 4.0 \\
\hline Difference & -0.4 \\
\hline
\end{tabular}

In accordance with the calculations of IFAS and EFAS, the position of leather craft in Sidoarjo District is as follows:

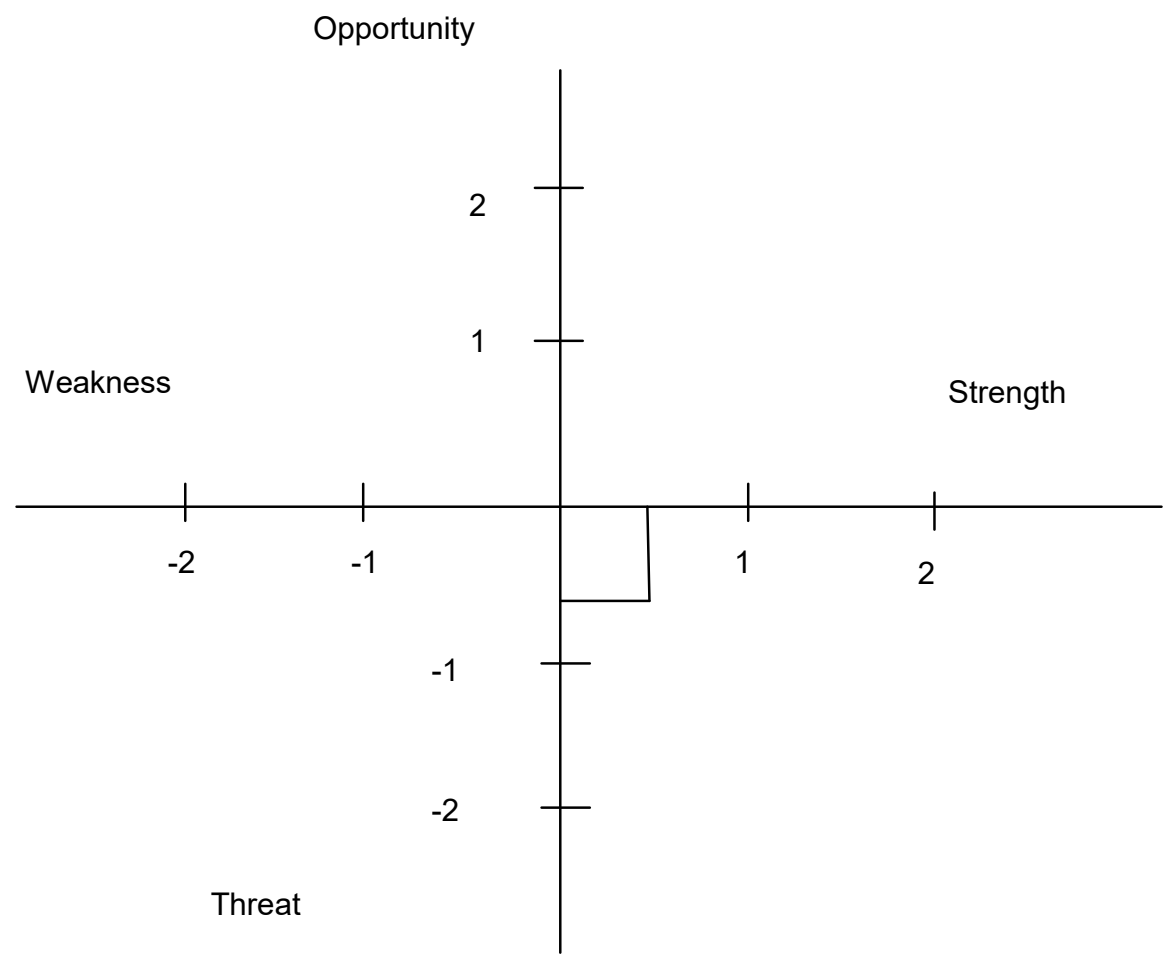

Figure 1 - The SWOT diagram shows that the position of the Sidoarjo leather processed craft is in the ST Quadrant 
The result of weighting and calculation with SWOT shows that ST strategy should be done namely diversification.

Table 4 - Strategy that is expected to be applied to Small Scale Business of Leather Products in Sidoarjo Regency

\begin{tabular}{|l|l|l|}
\hline & Strength $(\mathrm{S})$ & Weakness $(\mathrm{W})$ \\
\hline Opportunity (O) & $\begin{array}{l}\text { Online sales so that the goods will get more } \\
\text { recognition and can be bought by the public } \\
\text { Innovate products for the dominant market } \\
\begin{array}{l}\text { segment } \\
\text { Improve the human resources capability to } \\
\text { improve the quality of the already good product, to } \\
\text { make it better }\end{array}\end{array}$ & $\begin{array}{l}\text { Improve the bookkeeping system and } \\
\text { Selectively choose loan capital from the } \\
\text { bank }\end{array}$ \\
\hline Threat (T) & $\begin{array}{l}\text { Innovating and developing industrial products to } \\
\text { compete withimported products } \\
\text { Keeping and maintaining the good-quality } \\
\text { product. }\end{array}$ & $\begin{array}{l}\text { Empowering one worker to be able to } \\
\text { perform marketing and financial functions } \\
\text { Merger with other industry owners }\end{array}$ \\
\hline
\end{tabular}

A good and suitable strategy to implement is a diversification strategy. Some of the ways that can be done are innovation and development of industrial products that are not inferior to imported products. In addition, it is important to keep and maintain the quality of the product to stay good. This is in line with research conducted by Rahmana(2012) where the applied diversification strategy is to innovate products by utilizing technology and maintaining the quality of the product so as not to lose with imported products. Quality improvement can be done by continuously innovating, conducting training, monitoring product standards and conducting good cooperation with raw material suppliers so that the value chain can be well controlled. Forshman (2011) also believes that innovation program isalso suitable for small businesses. Hence, the sustainability of the business will be able to keep surviving.

A diversification strategy is a strategy the company undertakes to expand its business by opening a new business unit of either the same or different business type than the previous business (George, 2005). Sigh and Mahmood (2007) argue that diversification can have a positive impact on the business performance and can increase the generated profit and reduce the threat of external elements.

Diversification can also be done through various innovations in a business entity which can be considered as something of value (Java Post, 2003). Innovation will not be useful if it is not strategically meaningful, potentially productive, and gives the effect of continuity. A productive innovation can work in the field as good as the expectation. There are four levels of innovation namely creative, strategic, productive and sustainable.

- Creative Innovations is an innovative program or policy that is intelligent in terms of ideas and the potential to produce short-term positive effect although it has not shown any practical positive field.

- Strategic innovation is an innovative program or intelligent policy in terms of ideas, potentially providing both short- and long-term impacts that are positive. However, it has not been proven to be implemented in the field

- Productive innovation is an innovative program or intelligent policy in terms of ideas, potentially having a positive short-term impact and has been proven to be implemented in the field but not necessarily convincing for the long term.

- Continuous innovation is an innovative program or policy that is not only intelligent in terms of ideas, potentially positive in the short and long term but it has not been proven to be implemented in the field.

The innovation of a product is an important thing that should be done. A research conducted by Hidayat (2015) stated that the lack of innovation of a bag product derived from leather preparation making it difficult for small business to develop. Thus, the innovation process should be carried out to keep the business survive and thrive. 
In developing this processed leather craft, sustainable innovation strategy needs to be implemented. Thus, that leather processed crafters can continue to compete, produce good products and be well received by the market. Innovation by a producer or crafters can increase consumer interest in purchasing a production work (Livianne, 2013).Continuous innovation needs to be done and followed by the existence of the media campaign. Hence, the that creativity results that appear after the innovation can be recognized by the prospective buyer. In addition, promotions can also improve information about the quality of the product. Hence, it will ultimately increase the consumers' desire to buy such processed leather products (Pratama, 2017).

In its current development, Revolution 4.0 requires us to innovate and also pay attention to aspects of information technology which grows rapidly (Suwardana, 2018). Revolution 4.0 that combines digitalization and automation that combines the internet and manufacture. This can be used as an opportunity for small businesses such as the processed leather crafts that produce bags, luggage, and others to be able to market the product results more widely. Revolution 4.0 will increase the potential buyers, not only from one or two regions but also from all over Indonesia. This opportunity certainly needs to be supported by the readiness of crafters to have specialized human resources online saleand also provides a set of computers and the Internet as the supporting tools.

Currently, the expansion of buying and selling in Indonesia is very supportive for continuous innovation. The processed leather crafters can take advantage of various popular e-commerce in Indonesia. Various e-commerce such as Bukalapak, Olx, Shoope, Lazada and others can be utilized by the crafters to market their handicraft products either in the form of bags, luggage or others. Based on the research conducted by Mumtahana (2017), there is relationship between online sales with an increase in income. Thus, one aspect of Revolution 4.0 can essentially help leather crafters in Sidoarjo to market the product innovation globally in Indonesia. Hence, it will indirectly increase the marketing range and it is expected to increase the income of crafters in the end.

\section{CONCLUSION}

The processed leather industry located in Tanggulangin Sidoarjo has excellent internal strength but has weaknesses in external factors. The strategy that needs to be developed is the Diversification strategy. This needs to be done so that the processed leather craft can continue to survive and develop.

It is suggested for future researcher to research value chain of the raw material of the processed leather products. This is because raw materials become one of the important factors for the continuity of this small-scale business. Another interesting thing is that the raw material becomes crucial due to its dependency on the small supplier that only hopes for a fast profit. In addition, the auxiliary materials are still rare; they must be imported from China.

\section{REFERENCES}

1. Pratama, F.Y., 2017.The design of promotion media Intako Cooperative of TanggulanginSidoarjo. Thesis majoring in arts and design-faculty of literature University of Malang.

2. Liviane, M.S., 2013. The influence of consumer preference through brand value and the influence of product innovation through luxury brand towards willingness to pay a premium Louis Vuitton product in Surabaya.

3. Rahmana, A., 2012. Development Strategy of small and medium enterprise of processing industry sector. Journal of industrial engineering, 13(1), pp.14-21.

4. Hidayat, R.A., 2015. Development Strategy of small bag industry in Jati Sub-District Kudus Regency. Economics development analysis journal, 3(4).

5. Law no. 20 year 2008 about micro small and medium enterprises (MSME)

6. Satoto, S.H., 2009. Diversification strategy on the company performance. Journal of finance and banking, 13(2), pp.280-287. 
7. Azqiyah, W., 2016. Cooperative industrial of bag and luggage (intako) in Tanggulangin Sidoarjo year 1976-2013. Avatara, 4(2).

8. George, R., Kabit, R. 2005. Corporate diversification and firm performance: does

9. the organizational form of the firm matter? Fma annual meeting, chicago, pp.1-81.

10. Chakrabarti, A., Singh, K., \& Mahmood, I. 2007. Diversification and performance: evidence from East Asian firms. Strategic management journal, vol. 28, pp.101-120.

11. Forsman, H., 2011. Innovation capacity and innovation development in small enterprises. A comparison between the manufacturing and service sectors. Research Policy, 40(5), pp. 739-750.

12. Prastika, H.C., 2016. The role of local government and the participation of micro small medium enterprises (MSME) in the effort to develop leather handicraft in Magetan Regency (doctoral dissertation, Airlangga University).

13. Timur, B.J., 2006. GRDP of East Java Province. Government of East Java Level I.

14. Machmud, S. and Sidharta, I., 2013. Model of Strategic Management Appraisal Approach in Improving MSME Sector in Bandung (Model Study of Strategic Management Approach in SMEs Sector Improvement In Bandung). Computech \& Business Journals, 7(1), pp. 56-66.

15. Suwardana, H., 2018. Industrial Revolution 4. 0 Mental Revolution-Base. JATI UNIK: Journal of Scientific Engineering and Industrial Management, 1(2), pp.102-110.

16. Mumtahana, H.A., Nita, S. and Tito, A.W., 2017. Utilization of E-Commerce Web Site to Improve Marketing Strategy. KhazanahInformatika: Journal of Computer Science and Informatics, 3(1), pp.6-15. 